\title{
Normatywność etyki cnót środowiskowych na przykładzie etyki Ronalda Sandlera. Komentarz ${ }^{1}$
}

\author{
Dominika Dzwonkowska \\ Instytut Ekologii i Bioetyki \\ Uniwersytet Kardynała Stefana Wyszyńskiego w Warszawie \\ d.dzwonkowska@uksw.edu.pl \\ Przyjęto: 16 luty; zaakceptowano: 27 luty.
}

\begin{abstract}
Abstrakt
Celem mojej pracy jest wykazanie, że etyka cnót środowiskowych może być etyką normatywną. Po pierwsze przedstawię argumenty za tym, etyka cnót może być uznana za etykę normatywną (\$1). Po drugie wykażę, że normy etyki cnót różnią się od norm etyk deontologicznych i utylitarystycznych (§2). Analizę etyki cnót środowiskowych zawężę do ujęcia Ronalda Sandlera. Opierając się na jego poglądach, sformułuję maksymę ogólną i przesłanki, które określają, co jest działaniem właściwym (§3).
\end{abstract}

Słowa kluczowe: etyka cnót środowiskowych; normatywność; Ronald Sandler

W zbiorze esejów poświęconych zagadnieniom związanym z etyką i czasem Jacek Jaśtal pisze, że współczesna etyka cnót „to normatywna teoria etyczna, która prezentuje alternatywne podejście do takich teorii, jak utylitaryzm czy deontologizm” (Jaśtal, 2015, s. 7). Z drugą częścią tego stwierdzenia można się zgodzić, jednak jego pierwsza część budzi wątpliwości. Otóż współczesna etyka cnót nie jest tradycyjnie uznawana za etykę normatywną. Toczy się dyskusja wokół jej normatywnego charakteru. Zresztą Jaśtal zaraz prostuje cytowaną wypowiedź, dodając w kolejnym zdaniu, „że w roli teorii normatywnej etyka cnót wypada raczej słabo" (s. 17).

\footnotetext{
${ }^{1}$ Niniejszy artykuł został sfinansowany ze środków Narodowego Centrum Nauki przyznanych na podstawie decyzji numer 2017/01/X/HS1/01491. Pragnę podziękować Michałowi Piekarskiemu i Andrzejowi Waleszczyńskiemu cenne uwagi, które pomogły mi w napisaniu tego artykułu.
} 
Sam termin normatywność może być różnie rozumiany. Pojęcie to początkowo było związane z etyką i prawem, z czasem stało się przedmiotem analiz logiki, metodologii, epistemologii, ale także filozofii języka, filozofii umysłu i metaetyki (por. Duchliński i in., 2015, s. 19-21). Jak zauważa Piekarski: ,już pobieżna lektura opracowań dotyczących normatywności czy szybki przegląd baz bibliograficznych zawierających jako jedno ze słów kluczowych termin «normatywność» prowadzi do spostrzeżenia, że nie można mówić o niej tylko w jednym sensie” (Piekarski, 2018). W niniejszym artykule termin „normatywność” występuje w dwóch głównych znaczeniach wymienianych przez cytowanego filozofa: 1. „Normatywność to tyle, co pewne standardy etyczne, czyli sądy odnoszące się do tego, co być powinno i tego, co być nie powinno; [...] 2. Normatywność to własność tzw. etycznych i prawnych systemów normatywnych, tj. praw, kodeksów itd. Należy je rozumieć jako określone zbiory zdań praktycznych i teoretycznych powiązane związkami logicznymi i pozalogicznymi” (Piekarski, 2018; por. Duchliński i in., 2015, s. 28-30). Pisząc o etyce normatywnej mam na myśli teorię etyczną, w ramach której formułuje się normy ogólne dotyczące właściwego/niewłaściwego działania.

Dyskusję na temat normatywności etyki cnót opieram głównie na literaturze anglosaskiej, gdzie rozważania w tym temacie były związane z początkową radykalną krytyką etyk deontologicznych i utylitarystycznych (por. Szutta, 2012, s. 88). Współczesna etyka cnót powstała jako odpowiedź na niewystarczalność normatywnych teorii etycznych (Anscombe, 1958), którym zarzuca się między innymi nadmierny legalizm rozumiany jako formułowanie norm na wzór przepisów prawa (por. Jaśtal, 2015, s. 12; Sandler, 2007, s. 1). Tym, co odróżnia etykę cnót od etyk normatywnych, jest przesunięcie głównego obszaru refleksji z analizy (słuszności/niesłuszności) czynu na analizę (dobrego/złego) charakteru podmiotu moralnego (czyli jego cnót/wad). Ponadto przedstawiciele współczesnej etyki cnót zakwestionowali również sposób uzasadniania, w którym „z najogólniejszych, uniwersalnych zasad moralnych [...] wyprowadza się bardziej szczegółowe obowiązki. Krytyce poddano [...] uniwersalność zasad i obowiązków w obliczu różnorodności sprawców i sytuacji moralnych, z którymi trzeba się zmierzyć" (Szutta, 2012, s. 88). Zarzucano etyce normatywnej nie tylko legalizm norm etycznych, ale także próbę ujmowania moralności na wzór teorii w naukach empirycznych jako pewnego ogólnego, abstrakcyjnego prawa, które można przyłożyć do każdej sytuacji. Tego typu ujęcie nie pozwala na uwzględnianie różnorodności sprawców i sytuacji moralnych.

Jak zauważa Szutta: „etyka cnót powraca do teleologicznego uzasadniania moralności, w ramach którego uznaje się, że celem człowieka jest eudajmonia” (Szutta, 2012, s. 88). To rzeczywiście ogranicza możliwość formułowania norm ogólnych w pewnych obszarach, czyni etykę cnót bardziej indywidualistyczną i nieadekwatną do realizacji celu etyk normatywnych, jakim jest formułowanie ogólnych norm. Co więcej etycy cnót świadomie zrezygnowali z formułowania 
norm, które postrzegali jako nadmiernie legalistyczne. Jak pokażę w niniejszym tekście, to wszystko nie ogranicza jednak możliwości formułowania ogólnych norm w ramach etyki cnót, jakkolwiek jej normatywność jest odmienna od tej, jaką spotyka się w etykach deontologicznych i utylitarystycznych.

W niniejszym komentarzu postawię tezę, że etyka cnót, w tym również cnót środowiskowych, może być traktowana jako etyka normatywna. Swoje rozważania zawężę do etyki cnót środowiskowych w ujęciu Ronalda Sandlera. W tekście pokażę, że: 1. mimo iż etyka cnót nie skupia się w pierwszej kolejności na formułowaniu norm, to może być etyką normatywną i określać zasady słusznego działania nie mniej skutecznie niż etyki utylitarystyczne czy deontologiczne, 2. normy etyki cnót różnią się od norm etyk deontologicznych i utylitarystycznych, 3. etyka cnót środowiskowych również może być etyką normatywną. Tę tezę przedstawię na przykładzie etyki cnót środowiskowych w ujęciu Ronalda Sandlera. Opierając się na jego poglądach, sformułuję maksymę ogólną i przesłanki, które określają, co jest działaniem właściwym.

\section{Normatywna etyka cnót}

Przyjęło się uznawać, że etyka cnót nie formułuje norm ogólnych. Panuje powszechne przekonanie, iż „etyka cnót nie mówi nam, ponieważ nie jest w stanie, jak powinniśmy postępować. Tym samym nie może stanowić kontrpropozycji do teorii deontologicznej lub utylitaryzmu" (Hurtshouse, 2004, s. 192). Etyka cnót może zatem co najwyżej ograniczyć się do uzupełnienia teorii normatywnych bądź razem z nimi tworzyć kompletną teorię moralną (np. Frankena, 1958). Zdaniem Frankeny kompletna teoria moralna musi obejmować zarówno aretologię, jak i deontologię. Aretologia jest ugruntowana w teorii deontologicznej lub teleologicznej, „z której może czerpać swoją normatywność oraz uniwersalne zasady moralne, ułatwiające podejmowanie moralnie dobrych decyzji i wydawanie moralnych ocen. Natomiast teorie deontologiczne i teleologiczne domagają się uzupełnienia o etykę cnót, która zwraca uwagę na rolę edukacji moralnej sprawcy działania: odpowiedniego kształtowania jego motywów, dyspozycji i postaw” (Szutta, 2004, s. 171).

Zdaniem Hurtshouse zarzut, że etyka cnót nie daje wskazówek do działania, a skupia się jedynie na charakterze, nie ma uzasadnienia. Etyczka uważa, że również w przypadku etyki cnót można sformułować maksymę określającą, czym jest właściwe działanie. Brzmiałaby ona następująco: „Działanie jest właściwe, jeśli jest to działanie, jakie osoba pełna cnót podjęłaby w sposób dla siebie typowy (tj. zgodnie ze swoim charakterem w danych okolicznościach)" (Hurtshouse, 2004, s. 194). Maksyma ta ma jednak wciąż ogólny charakter i nie daje wskazówek do działania w konkretnych przypadkach. Niemniej, jak argumentuje filozofka, maksymy etyk utylitarystycznych czy deontologicznych są równie ogólne. Sformułowania takie jak: „działanie jest właściwe wtedy i tylko 
wtedy, gdy przyczynia się do najlepszych skutków” (s. 192-193) oraz „działanie jest słuszne wtedy i tylko wtedy, gdy powstaje w zgodzie z poprawną regułą lub zasadą moralną” (s. 192-193) są również bardzo ogólne i nie dostarczają praktycznych wskazówek do działania. Dopiero dookreślenie ich treści w drugiej (a ewentualnie i w kolejnych) przesłankach daje nam wiedzę o tym, jakie działanie jest właściwe. Przesłanki uzupełniające dla etyk deontologicznych czy utylitarystycznych precyzowałyby, jak rozumieć najlepsze skutki bądź poprawną regułę, a w przypadku etyki cnót mogłyby uściślać to, co rozumie się przez określenia „osoba pełna cnót” czy „cnota”.

Możliwość sformułowania maksymy ogólnej określającej, czym jest słuszne działanie, jest zatem przesłanką, by traktować etyki cnót jako etyki normatywne. Sama maksyma ogólna etyki cnót nie jest jeszcze źródłem wiedzy o tym, jak należy postępować w konkretnej sytuacji, stąd kluczowe znaczenie ma dookreślenie podstawowych terminów maksymy ogólnej w przesłankach. Jednak jak zauważa Jaśtal (2015, s. 7) normatywność etyki cnót jest inna od normatywności etyk oświeceniowych. Tym, co ją odróżnia, jest inny sposób uzasadnienia słuszności czynu, który wpływa również na sposób sformułowania jej norm.

\section{Specyfika normatywności etyki cnót}

Jak wskazuje Hurtshouse, etyka cnót może być uznawana za etykę normatywną. Niemniej odmienny od tradycyjnych etyk normatywnych przedmiot refleksji sprawia, że jej normatywność jest innego rodzaju. Kluczowe w przypadku etyki cnót jest to, że skupiając się bardziej na byciu dobrym niż na słusznym działaniu, formułuje się inne reguły niż te, które są charakterystyczne dla etyk deontologicznych i utylitarystycznych. Reguły te są nazywane w literaturze regułami cnót. Tym, co je wyróżnia jest to, że „ucieleśniają istotę cnoty” (por. Sandler, 2007, s. 7). Są to reguły, które odnoszą się do cnót i wad. Ich przykładowe sformułowania to: „czyń to, co uczciwe/dobroczynne” bądź „nie czyń tego, co nieuczciwe/niedobroczynne" (por. Hurtshouse, 1999). Co ciekawe, zdaniem Hurtshouse (2016) lista terminów odnoszących się do cnót jest względnie ograniczona, podczas gdy lista odniesień do wad jest w tym przypadku imponująca w porównaniu z normami etyk deontologicznych.

Etykę cnót odróżnia więc od innych ujęć etyki fakt, że jej normatywność jest oparta na cnotach i wadach. „To właśnie poprzez wyrażenie, czym są cnoty i wady teoria (etyczna) wyjaśnia, jaką osobą należy być oraz co należy czynić w konkretnej sytuacji” (Sandler, 2018, s. 233). Uzasadnieniem dla określonego działania jest odwołanie się do cnoty (o ile jest to reguła zalecająca słuszne działanie) lub do wady (gdy mówimy o regule zakazującej działania niesłusznego). Jednak powiązanie słuszności czynu i cnotliwości jest kłopotliwe ze względów teoretycznych. Hurtshouse (2016) zwraca uwagę na zarzut o ekstensjonalnej nieadekwatności, zgodnie z którym podkreśla się, że podmiot moralny może 
działać słusznie nie będąc cnotliwym, a osoba cnotliwa może czasami podejmować niesłuszne działania. Świadczy to o tym, że zależność między cnotliwością a słusznością podejmowanych przez podmiot moralny działań może być słaba. Wielu etyków (Anscombe, 1958; MacIntyre, 1996; Brewer, 2009) twierdzi, że słuszność/niesłuszność czynu jest niewłaściwym punktem wyjścia dla tej dyskusji, ponieważ kategorie te zostały powiązane z pojęciem moralnego obowiązku, tym samym są uwikłane w kontekst teoretyczny, którego etyka cnót nie potrzebuje.

W moim przekonaniu mimo wspomnianych trudności odwołanie się do cnót i wad oraz do charakteru człowieka jest solidnym fundamentem dla etyki. Wynika to $\mathrm{z}$ faktu, że rozpoznanie powinności moralnej i właściwy wybór odpowiedniego działania są łatwiejsze dla człowieka cnotliwego niż dla osoby niecnotliwej. Rozpoznanie powinności i właściwego działania u osoby cnotliwej wynika bowiem z jej naturalnych skłonności (jaką jest cnotliwy charakter), a nie jest podyktowane narzuconymi z zewnątrz normami. Chociaż jak zauważa Hurtshouse bycie cnotliwym nie jest warunkiem sine qua non ani gwarancją słusznego działania, to jednak osoba cnotliwa kierując się swoim charakterem ma zdolność dostrzegania zobowiązań moralnych, ponadto w razie sytuacji konfliktowej większą umiejętność podejmowania działania adekwatnego do sytuacji.

Owo rozpoznanie jest kluczowe, ponieważ reguły cnót nie są tak precyzyjnie wyrażone jak reguły deontologiczne. Przede wszystkim zawierają terminy wartościujące i pojęcia pojemne ${ }^{2}$ (por. Hurtshouse, 2004, s. 198-199), co sprawia, że są mniej precyzyjne od reguł deontologicznych. $Z$ tego powodu często są odrzucane w edukacji moralnej, gdzie argumentuje się, że są zbyt niejednoznaczne, by mogło je zrozumieć dziecko³. Właśnie ta nieprecyzyjność reguł cnót tym bardziej przemawia za tym, że osoby cnotliwe mają przewagę we właściwym dobraniu słusznego działania w sytuacji moralnej.

\section{Normatywna etyka cnót środowiskowych w ujęciu Ronalda Sandlera}

W kontekście normatywności etyki cnót ciekawym przypadkiem do analizy wydaje się etyka cnót środowiskowych, która powstała z zaniepokojenia kryzysem ekologicznym. Etyka ta podejmuje zagadnienie charakteru podmiotu moral-

\footnotetext{
${ }^{2}$ To znaczy tak szerokie, że mogą być rozumiane na więcej niż jeden sposób. Dokładne wyjaśnienie pojęć pojemnych w etyce można znaleźć w (Williams, 2006, s. 129-145). Samo słowo „pojemne” jako tłumaczenie dla angielskiego thick zostało zaproponowane przez Jacka Jaśtala w jego przekładzie tekstu Rosalind Hurtshouse.

${ }^{3}$ Hurtshouse (2004, s. 199-200) zwraca jednak uwagę, że w procesie wychowawczym dzieci posługujemy się nie tylko regułami deontologicznymi, ale także i pojęciami pojemnymi. Argument z pojemności pojęć nie wyklucza zatem formułowania norm etyki cnót.
} 
nego w kontekście jego zdolności do powstrzymania skutków degradacji środowiska i dbania o otoczenie przyrodnicze i społeczne. Sama dyscyplina zrodziła się na fali renesansu etyki cnót jako odpowiedź na niewystarczalność dotychczasowych ujęć etycznych w podejmowaniu kwestii relacji człowieka do środowiska i moralnego wymiaru tej relacji ${ }^{4}$. Etyka cnót środowiskowych wypracowała cztery samodzielne koncepcje: (1) ujęcie Henry'ego Davida Thoreau (w interpretacji Philipa Cafaro) ${ }^{5}$, (2) Louke'a van Wensveena (2000), (3) Ronalda Sandlera (2007) oraz (4) Briana Treanora (2014). W niniejszym tekście skupię się na ujęciu etyki cnót w myśli Sandlera.

W obliczu postępującej degradacji środowiska przyrodniczego normatywność etyki cnót środowiskowych może mieć kluczowe znaczenie dla możliwości trwania życia (w tym także ludzkiego) na Ziemi. Zdaniem Sandlera ludzka natura ma charakter normatywny, stanowi bowiem źródło informacji dla konstruowania norm etycznych nie determinując ich i dostarcza przesłanek na temat tego, co służy pełnemu rozwojowi osobowemu podmiotu moralnego (por. Sandler, 2012, s. 171). Sandler przyjmuje, za Philippą Foot (2001) oraz Rosalind Hurtshouse (1999), naturalistyczną koncepcję dobra. Jej istotą jest ufundowanie koncepcji dobra oraz cnoty na poszanowaniu biologicznych potrzeb i natury człowieka. To dostrzeżenie i poszanowanie jego biologicznej natury pozwala pozostać w łączności ze środowiskiem naturalnym, a dzięki temu lepiej je chronić. Jednocześnie pokazuje człowieka jako byt determinowany biologią, ale i wykraczający poza nią, ponieważ spełnianie celów biologicznych ${ }^{6}$ czło- $^{-}$ wieka stanowi fundament cnotliwości., Obraz człowieka w ramach tej koncepcji nie ogranicza się jednak tylko do tego, człowiek jest także istotą społeczną, racjonalną, zdolną do nadania sensu własnemu życiu, jak również skłonną do realizowania dobra, które nie służy tylko i wyłącznie podmiotowi moralnemu (określane przez Sandlera jako realizowanie nie-eudajmonistycznych celów). Takie ujęcie cnotliwego człowieka mogłoby uzupełniać maksymę ogólną zaproponowaną przez Hurtshouse. Dodatkowo należałoby wyjaśnić, co jest cnotą środowiskową.

\footnotetext{
${ }^{4}$ Za symboliczny początek dyscypliny uznaje się artykuł Thomasa Jr. Hilla Ideals of Human Excellence and Preserving Natural Environment (Hill, 1983), chociaż przedstawiciele dyscypliny podkreślają, że dyskusja aretologiczna była obecna już w transcendentalizmie amerykańskim, który jest uważany za główną inspirację refleksji środowiskowej w etyce (Por. Tyburski, 2006, s. 8-9).

${ }^{5}$ Wprawdzie Henry D. Thoreau jest jedną z kluczowych postaci ruchu ekologicznego w Stanach Zjednoczonych, to jego dorobek jest bardziej literacki niż filozoficzny. Niemniej ze względu na duże znaczenie dla kultury amerykańskiej jest często punktem wyjścia szerszych analiz filozoficznych, jak w przypadku zagadnienia cnót środowiskowych. Temat ten opracował i przedstawił Philip Cafaro (Cafaro, 2004).

${ }^{6}$ Przez cele biologiczne Sandler rozumie zaspokajanie potrzeb fizjologicznych (jak na przykład dostarczanie odpowiedniej ilości składników odżywczych, snu czy dążenie do przedłużenia gatunku).
} 
Biorąc pod uwagę powyższe rozważania w ramach etyki cnót środowiskowych w ujęciu Sandlera, można zaproponować następującą maksymę ogólną oraz przesłanki, określające czym jest słuszne działanie, kim jest cnotliwy człowiek i czym jest cnota środowiskowa:

1. „Działanie jest właściwe, jeśli jest to działanie, jakie osoba pełna cnót (środowiskowych) podjęłaby w sposób dla siebie typowy (tj. zgodnie ze swoim charakterem w danych okolicznościach)" (por. Hurtshouse, 2004, s. 194).

2. Człowiek jest cnotliwy, „gdy jest odpowiednio przygotowany na poziomie (i) emocji, (ii) pragnień i (iii) działania (kierowanego przez rozum i własne skłonności) do następujących funkcji: 1. przetrwania, 2. zapewnienia kontynuacji gatunku, 3. zapewnienia sobie wolności od bólu i odpowiednich dla niego przyjemności, 4. zdolności do dobrego funkcjonowania w społeczeństwie, 5. autonomiczności, 6. zdolności gromadzenia wiedzy, 7. prowadzenia życia, które ma znaczenie i 8. realizacji dowolnych nie-eudajmonistycznych celów (ufundowanych na nieeudajmonistycznych dobrach i wartościach) w sposób charakterystyczny dla człowieka (tj. w sposób, który może być postrzegany jako słuszny)”. (Sandler, 2007, s. 28)

3. Cnotą środowiskową jest cecha charakteru, która jest uzasadniania przez dobra lub wartości ekologiczne; odpowiada na byty środowiskowe lub realizuje cele środowiskowe (por. Sandler, 2018, s. 224-225)7.

Stanowisko Sandlera pozwala bardzo wyraźnie określić sposób rozumienia człowieka cnotliwego jako podmiotu, który realizuje zarówno swoje cele biologiczne, jak i cele życiowe wykraczające poza te determinowane biologią. Jednocześnie pozwala sprecyzować, co jest cnotą środowiskową, a także poznać przykłady tychże cnót oraz odpowiadających im wad (por. Sandler, 2018, s. 225). Na

\footnotetext{
${ }^{7}$ To dookreślenie, czym jest słuszne działanie oraz czym są cnoty, można by poszerzyć punkt V1c, który prezentowałby katalog cnót środowiskowych według Sandlera. Jego zdaniem cnoty środowiskowe można przedstawić w 6 głównych grupach: 1. Cnoty ziemi, zainspirowane etyką Aldo Leopolda, które czynią człowieka dobrym obywatelem biotycznej wspólnoty życia. Przykładami tych cnót są: miłość, wgląd na innych, dostrojenie (dostosowanie się), wrażliwość ekologiczna, wdzięczność (w publikacji z 2018 roku ta grupa już nie pojawia się). 2. Cnoty trwałości, które promują jedność ekosystemu, tak, aby ten mógł wyprodukować dobra niezbędne do ludzkiego pełnego rozwoju osobowego. Przykładami cnót w tej grupie są: umiarkowanie, oszczędność, dalekowzroczność, dostrojenie (dostosowanie się) czy pokora. 3. Cnoty jedności z przyrodą - są to dyspozycje, które pomagają człowiekowi cieszyć się i czerpać korzyści ze środowiska naturalnego. Są to na przykład: zadziwienie, otwartość, wrażliwość estetyczna, uważność czy miłość. 4. Cnoty szacunku wobec przyrody, jak na przykład: troska, współczucie, restytucyjna sprawiedliwość, niekrzywdzenie, wrażliwość ekologiczna. W katalogu z 2018 roku ta grupa jest określana jako cnoty szacunku wobec przyrody/zwierząt. 5. Cnoty środowiskowego aktywizmu są to cnoty związane z podtrzymywaniem dóbr z definicji cnót trwałości oraz korzyści z definicji cnót jedności z przyrodą. Wśród nich Sandler wymienia: gotowość do współpracy, wytrwałość, zaangażowanie, optymizm i kreatywność. 6. Cnoty związane z włodarzowaniem środowiskiem (stewardship), Sandler podaje dla nich takie samo określenie jak dla cnót związanych z aktywizmem środowiskowym. Do tej kategorii należą: uczynność, lojalność, sprawiedliwość, uczciwość i pracowitość (por. Sandler, 2007, s. 82; Sandler, 2018, s. 226).
} 
podstawie ogólnej maksymy zaproponowanej przez Hurtshouse dla określenia, czym jest właściwe postępowanie, oraz przesłanek wynikających z poglądów Sandlera można dokładnie określić, czym jest słuszne działanie z perspektywy etyki cnót środowiskowych, tym samym potwierdzając jej normatywność.

\section{Podsumowanie}

Tradycyjnie etyka cnót nie jest postrzegana jako etyka normatywna, co więcej krytyczne nastawienie do etyk normatywnych, towarzyszące początkom współczesnego renesansu etyki cnót może potęgować postrzeganie jej jako nienormatywnej tradycji etycznej. Jednak, jak wykazałam, istnieją stanowiska wskazujące na normatywność etyki cnót oraz uzasadniające jej normatywność w sposób równie pewny jak w przypadku etyk deontologicznych i utylitarystycznych.

Mimo porównywalnej pewności maksym ogólnych, zdolność określania, czym jest słuszne działanie z perspektywy etyki cnót, jest odmienna niż w przypadku oświeceniowych etyk normatywnych. Specyfiką normatywności etyki cnót jest jej oparcie na koncepcji cnót i wad oraz na tym, że punktem wyjścia jest określenie, jaką osobą powinno się być. Dopiero wzorcowy charakter moralny staje się punktem wyjścia i uzasadnieniem dla określenia, w jaki sposób należy postępować w określonych sytuacjach. Podzielam pogląd etyków cnót, że „wysoka kondycja moralna sprawców zagwarantuje moralnie dobre działanie” (por. Szutta, 2012, s. 89). Można więc twierdzić, że bycie cnotliwym w większym stopniu gwarantuje podjęcie właściwych działań niż kierowanie się narzuconymi z zewnątrz normami. Wynika to z faktu, że posiadanie cnót znacząco ułatwia podejmowanie słusznego działania. Cnotliwemu podmiotowi moralnemu łatwiej jest rozpoznać, jakie działanie powinno być podjęte oraz podejmować słuszne decyzje w przypadku konfliktu norm. Cnotliwość pełni tutaj rolę kompasu moralnego, który prowadzi podmiot moralny lepiej niż dowolne zbiory zasad i norm moralnych. Uważam, że aretologia powinna być traktowana nie jedynie jako uzupełnienie etyk normatywnych, ale również jako specyficzny przypadek etyki normatywnej. Co więcej normatywność jest możliwa nawet w przypadku etyk cnót z zawężonym polem refleksji, jak w przypadku etyki cnót środowiskowych w ujęciu Ronalda Sandlera.

\section{Bibliografia}

Anscombe, G. E. M. (1958). Modern Moral Philosophy. Philosophy, 33(124), 1-19.

Brewer, T. (2009). The Retrieval of Ethics. Oxford: Oxford University Press.

Duchliński, P., Kobyliński, A., Moń, R., Podrez, E. (2015). O normatywności $w$ etyce. Kraków: WAM.

Foot, P. (2001). Natural Goodness. Oxford: Oxford University Press. 
Frankena, W. K. (1958). Toward a Philosophy of Moral Education. Harvard Education Review, 28, 300-313.

Hill, Th. Jr. (1983). Ideals of Human Excellence and Preserving Natural Environment. Environmental Ethics, 5(3), 211-224.

Hurtshouse, R. (2004). Normatywna etyka cnót. W: J. Jaśtal (red.), Etyka i charakter (ss. 191-209). Kraków: Aureus.

Hurtshouse, R. (1999). On Virtue Ethics. Oxford: Oxford University Press.

Hursthouse, R., Pettigrove, G. (2016). Virtue Ethics, W: E. N. Zalta (ed.), The Stanford Encyclopedia of Philosophy (Winter 2016 Edition). Źródło: $<$ https://plato.stanford.edu/archives/win2016/entries/ethics-virtue/>.

Jaśtal, J. (2015). Etyka i czas. Wariacje aretologiczne. Kraków: Księgarnia Akademicka.

MacIntyre, A. (1996). Dziedzictwo cnoty. Studium z teorii moralności. Warszawa: PWN.

Piekarski, M. (2018). One or many normativities? Studia Philosophiae Christianae, 54(1), Filozofia normatywności.

Sandler, R. (2007). Character and Environment. A Virtue-Oriented Approach to Environmental Ethics. Nowy Jork: Columbia University Press.

Sandler, R. (2018). Environmental Ethics. Theory in Practice. Oxford: Oxford University Press.

Sandler, R. (2012). The Ethics of Species. Cambridge: Cambridge University Press.

Szutta, N. (2012). Dyskusja z sytuacjonistyczną krytyką etyki cnót. Odpowiedź na zarzuty Gilberta Harmana. Diametros, 31, 88-112.

Szutta, N. (2007). Wspótczesna etyka cnót. Gdańsk: Wydawnictwo Uniwersytetu Gdańskiego.

Thoreau, H. D. (2011). Walden, czyli życie w lesie. Poznań: Rebis.

Treanor, B. (2014). Emplotting Virtue: A Narrative Approach to Environmental Virtue Ethics. Albany: SUNY Press.

Tyburski, W. (2006). Powstanie i rozwój filozofii ekologicznej. Problemy Ekorozwoju, 1(1), 7-15.

Williams, B. (2006). Ethics and the Limits of Philosophy. Abingdon: Routledge

Van Wensveen, L. (2000). Dirty Virtues: The Emergence of Ecological Virtue Ethics. Nowy Jork: Prometheus Books. 


\title{
Normativity of environmental virtue ethics on the example of Ronald Sandler's ethics: a commentary
}

\begin{abstract}
The aim of my article is to prove that environmental virtue ethics (EVE) can be a normative ethics. First I will present the arguments that virtue ethics can be a normative ethics (§1). Second I will demonstrate that the norms of virtue ethics are different than the norms of a utilitarian or deontological ethics (§ 2). Third I will propose the general maxim and premises stating what is the right action according to Ronald Sandler's EVE (§3).
\end{abstract}

Keywords: environmental virtue ethics, normativity, Ronald Sandler 